\title{
KUTTAB SEBAGAI PUSAT ILMU PENGETAHUAN PENDIDIKAN ISLAM
}

\author{
Emna Laisa \\ Institut Agama Islam Negeri Madura \\ e2nk.cute@gmail.com
}

\begin{abstract}
Kuttab has a strategic role in shaping the youth of Islam in the classical era. It is not only excelled in the religious and moral aspects, but also plays a role in the increased intellectual and life skills. Kuttab development from the Prophet era until the Abbasid Daula characterized in each period, in terms of the development of course materials, teaching methods, to community participation. In the midst political conflict, the existence kuttab always in a dynamic conditions. This is evident shows since kuttab just a personal waqf institution to become a major educational institution who participated managed by the government. Kuttab not only sparkling in the golden age, but kuttab inspire the implementation of the Full Day School in Indonesian Islamic educational institutions. It lies the urgency of term al-muhafadzah ala al-qadim al-shalih wa al-akhdu bi al-jadid al-ashlah, that the classical Islamic education system is able to be a reference to answer the problems of education in the contemporary era.
\end{abstract}

\section{ABSTRAK}

Kuttab memiliki peran strategis dalam upaya pembentukan generasi muda Islam di era klasik. Kuttab tidak hanya unggul dalam aspek keagamaan dan moral, namun juga berperan dalam peningkatan intelektualitas dan kecakapan hidup. Perkembangan kuttab dari masa Rasulullah hingga Daulah Abbasiyah memiliki ciri khas dalam setiap periodesasinya, baik ditinjau dari pengembangan materi pelajaran, metode pembelajaran, hingga peran serta masyarakat. Di tengah suasana konflik politik yang berkecamuk, eksistensi kuttab senantiasa berada dalam kondisi dinamis.

\section{ARTICLE HISTORY}

Received 10 Agustus 2020

Revised 20 Agustus 2020

Accepted 25 Agustus 2020

\section{KEYWORDS}

Kuttab, Development of Kuttab, Full Day School Approach. 
Hal ini tampak sejak kuttab hanya berupa institusi wakaf pribadi hingga menjadi institusi pendidikan besar yang turut serta dikelola pemerintah. Kuttab tidak hanya bersinar di masa keemasannya, tetapi telah menginspirasi pemberlakuan Full Day School di lembaga pendidikan Islam, khususnya di Indonesia. Di sinilah letak urgensi al-muhafadzah ala al-qadim al-shalih wa al-akhdu bi al-jadid alashlah, bahwa sistem pendidikan Islam klasik mampu dijadikan rujukan untuk menjawab masalah pendidikan di era kekinian.

\section{PENDAHULUAN}

Institusi pendidikan merupakan lembaga yang berfungsi sebagai sebuah sistem sekaligus sarana kegiatan pendidikan dalam rangka menjawab kebutuhan peserta didik dan masyarakat. ${ }^{1}$ Keberadaannya memberikan nuansa pencerahan bagi peradaban umat manusia pada masanya. Berbagai inovasi dan penemuan penting lahir dan berkembang melalui institusi pendidikan.

Dalam sistem pendidikan Islam klasik, terdapat keterkaitan erat antara pendidikan Islam dan wakaf dengan memposisikan lembaga wakaf sebagai sumber pendanaan kegiatan pendidikan Islam. Adanya sistem wakaf dalam Islam berhubungan dengan sistem ekonomi Islam yang berasumsi bahwa sektor ekonomi memiliki relasi kuat dengan akidah dan syariat Islam. Adanya keseimbangan antara ekonomi dan kemaslahatan masyarakat berimplikasi terhadap orientasi aktivitas ekonomi yakni sebagai sarana ibadah dan menyejahterakan umat. $^{2}$

Eksistensi wakaf memiliki kontribusi besar dalam menopang kegiatan pendidikan. Melalui wakaf, umat Islam memperoleh kemudahan dalam menuntut ilmu karena adanya subsidi biaya pendidikan yang berimplikasi pada pemerataan kesempatan belajar, bahkan peserta didik yang kurang mampu bisa memperoleh fasilitas penunjang aktivitas pendidikannya secara gratis.

\footnotetext{
${ }^{1}$ Abuddin Nata, Sejarah Sosial Intelektual Islam dan Institusi Pendidikannya (Jakarta: Rajawali Pers, 2012), 200.

2 Hanun Asrahah, Sejarah Pendidikan Islam (Jakarta: PT. Logos Wacana Ilmu, 1999), 91.
} 
Kuttab sebagai sebuah lembaga pendidikan dasar memiliki peran yang sangat strategis dalam upaya mencerdaskan generasi muda (anak-anak). Masa Rasulullah, khulafa al-Rasyidin dan dinasti Umayyah diibaratkan fase menyemai bibit menjadi tunas hingga mencapai fase kemajuan yang signifikan pada dinasti Abbasiyah. Oleh karena itu, penulis berupaya menyajikan fakta sejarah perkembangan kuttab sebagai lembaga pendidikan Islam klasik melalui penelitian studi pustaka. Berbagai keberhasilan kuttab masa klasik tersebut dapat dijadikan solusi alternatif dalam upaya pengembangan sistem pendidikan Islam di masa berikutnya.

\section{PEMBAHASAN}

\section{Sejarah Kuttab}

Menurut catatan sejarah, dalam dunia Islam telah berkembang lembaga pendidikan Islam nonformal, salah satu di antaranya adalah kuttab atau maktab jauh sebelum munculnya lembaga pendidikan formal. Kuttab atau maktab berasal dari kataba yang bermakna menulis atau tempat menulis. Secara garis besar, kuttab didefinisikan sebagai tempat belajar menulis sekaligus lembaga pendidikan tingkat dasar. ${ }^{3}$ Terdapat perbedaan pendapat tentang makna kuttab dan maktab. Beberapa tokoh menyatakan bahwa keduanya memiliki makna yang sama, namun ada juga yang mengatakan berbeda. ${ }^{4}$

\footnotetext{
${ }^{3}$ Suwito, Sejarah Sosial Pendidikan Islam (Jakarta: Kencana, 2005),12.

${ }^{4}$ George Makdisi menyatakan bahwa kuttab berbeda dengan maktab. Menurutnya, maktab merupakan jenjang pendidikan sebelum kuttab, hal ini dapat dilihat dari pembelajaran di Nisapur, bahwa pada usia lima tahun, Abd al-Ghafir al-Farisi belajar al-Qur'an dan ilmu agama di maktab. Kemudian di usia sepuluh tahun, ia melanjutkan ke kuttab untuk belajar sastra. Selanjutnya ia menjelaskan pula bahwa maktab adalah sekolah dasar pertama yang mengajarkan khat, kaligrafi, al-Qur'an, akidah, dan syair. Periksa, George Makdisi, The Rise of Colleges (Edinburg: Edinburg University Press, 1981), 19. Muniruddin Ahmed berpendapat bahwa maktab adalah tempat belajar, sedangkan kuttab adalah sebutan bagi pelajar di maktab. Lihat, Asrahah, Sejarah Pendidikan Islam, 47-48. Abdullah Fajar berpendapat bahwa maktab adalah istilah untuk masa klasik, sedangkan kuttab untuk zaman modern. Periksa, Abdullah Fajar, Peradaban dan Pendidikan Islam (Jakarta: Rajawali Press, 1996), 16.
} 
Kuttab $^{5}$ sebenarnya telah ada di jazirah Arab pada masa pra Islam. ${ }^{6}$ Namun pada saat itu orientasi masyarakat belum mengarah pada pendidikan dan kuttab kurang mendapat perhatian. Hal ini terbukti sebelum kedatangan Islam, hanya 17 laki-laki dan 5 orang perempuan Quraisy yang menguasai baca tulis. ${ }^{7}$. Adapun orang yang pertama kali belajar membaca dan menulis di antara penduduk Mekkah adalah Sufyan Ibn Umayyah dan Abu Qais ibn `Abd alManaf yang belajar kepada Bisyr ibn `Abd al-Malik. Kepada keduanyalah penduduk Mekkah belajar membaca dan menulis dengan bayaran suka rela. ${ }^{8}$

Pada awal Islam, kuttab hanya sebuah ruangan di kamar seorang pendidik dengan menggunakan sistem wetonan. ${ }^{9}$ Setelah kekuasaan kaum muslimin semakin meluas, bertambah pula jumlah penduduk yang memeluk Islam sehingga membutuhkan tempat yang lebih besar. Kuttab pun mengalami perkembangan yang signifikan hingga mampu menyediakan fasilitas asrama dan akomodasi bagi para peserta didiknya.

Biaya selama belajar di kuttab pada dasarnya dibebankan kepada orang tua murid dengan membayar sejumlah uang atau bahan makanan setiap minggu atau bulan. Pendidikan di kuttab adalah untuk semua orang, tidak ada diskriminasi dalam belajar antara yang kaya dengan yang miskin. Bahkan ada sebagian anak miskin yang belajar di kuttab memperoleh makanan dan pakaian

\footnotetext{
${ }^{5}$ Dalam hal ini perlu dibedakan antara kuttab yang mengajarkan baca tulis dengan kuttab yang mengajarkan al-Qur'an. Kuttab jenis baca tulis telah ada sejak zaman pra Islam, sedangkan kuttab yang mengajarkan al-Qur'an baru ditemukan setelah adanya syiar Islam. Namun kuttab yang mengajarkan al-Qur'an tidak didapati pada permulaan Islam karena pada saat itu masih sedikit orang yang hafal al-Quran dan suatu hal yang langka. Lihat, Ahmad Syalabi, Sejarah Pendidikan Islam(terj. Muhtar Yahya) (Jakarta: Bulan Bintang, 1973), 40. Namun setelah Islam semakin meluas, materi pembelajaran tidak hanya terbatas pada membaca dan menulis, melainkan ditambah dengan kemampuan membaca al-Qur'an secara tajwid. Periksa, Imron Fauzi, Manajemen Pendidikan Ala Rasulullah (Jogjakarta: Ar-Ruzz Media, 2012), 137.

${ }^{6}$ Kuttab era pra Islam juga digunakan sebagai tempat pengajaran kitab Taurat dan Injil yang ditujukan untuk menyebarkan ajaran Yahudi dan Kristen terhadap pemeluk Majusi dan masyarakat Arab Pagan. Lihat, Hasan Asari, Menyingkap Zaman Keemasan Islam (Bandung: Mizan, 1984), 17-18.

${ }^{7}$ Suwendi, Sejarah dan Pemikiran Pendidikan Islam (Bandung: Raja Grafindo Persada, 2004), 9.

${ }^{8}$ Mahmud Yunus, Sejarah Pendidikan Islam (Jakarta: Hidakarya Agung, 1992), 19-20.

9 Wetonan ialah penyampaian pelajaran di mana seorang guru membacakan kitab dan menerangkannya di hadapan sekelompok murid. Lihat, Nur Uhbiyati, Ilmu Pendidikan Islam (Bandung: CV. Pustaka Setia, 2005), 142.
} 
cuma-cuma, hal ini merupakan implikasi dari sistem wakaf yang diterapkan dalam pendidikan.

Pendidikan tingkat rendah di kuttab juga diberikan di istana untuk putra-putri pejabat negara, hal ini dimaksudkan sebagai persiapan proses regenerasi kepemimpinan dengan menyiapkan anak didik agar mampu melaksanakan tugas-tugas kenegaraan setelah dewasa. Oleh sebab itu, para pejabat negara mendatangkan guru-guru khusus untuk mendidik anak-anak mereka. Corak pendidikan anak-anak di istana memiliki perbedaan dengan di kuttab, rencana pelajaran dibuat oleh orang tua peserta didik menyesuaikan dengan hasil yang ingin dicapai dengan menambah atau mengurangi rencana pelajaran di kuttab pada umumnya.

Perbedaan yang lain antara kuttab dengan pendidikan rendah istana terletak pada penyebutan muallim pada guru di kuttab dan muaddib terhadap guru pendidikan rendah istana. ${ }^{10}$ Di samping itu juga terdapat pengklasifikasian guru yang menempatkan muallim kuttab mempunyai status sosial rendah, sedangkan muaddib pendidikan rendah istana mempunyai status sosial yang tinggi. ${ }^{11}$

\section{Perkembangan Kuttab periode Rasulullah}

Mengingat jumlah umat Islam yang bisa baca tulis sangat sedikit dan telah menjadi sekretaris-sekretaris Nabi Muhammad untuk menulis wahyu ${ }^{12}$, maka Rasulullah merekrut orang-orang dzimmi untuk mengajar baca tulis di

\footnotetext{
10 Mehdi Nakosteen, History of Islamic Origins of Western Education A.D 800-1350 (Colorado: University of Colorado Press, 1964), 46.

${ }^{11}$ Al-Jahiz mengklasifikasikan guru ke dalam 3 golongan: pertama, guru di kuttab mempunyai status sosial rendah karena ada yang kualitas keilmuannya dangkal dan kurang berbobot. Kedua, guru di istana, status sosialnya tinggi karena memiliki persyaratan alim, berakhlak mulia, dan dikenal masyarakat. Ketiga, guru yang memberikan pelajaran di masjid dan sekolah karena penguasaan ilmu pengetahuan yang mendalam (rasikh) dan berbobot. Lihat, Abuddin Nata, Sejarah Pendidikan Islam Pada Periode Klasik dan Pertengahan (Jakarta: Rajawali Pers, 2012), 146-147.

12 Sahabat Rasulullah yang bisa membaca dan menulis antara lain Abu Bakar, Umar bin Khattab, Utsman bin Affan, Abdullah bin Amr bin al-Ash, dan sebagainya. Sedangkan dari kaum perempuan misalnya Hafshah istri Rasulullah dan Ummu Kultsum binti Uqbah. Lihat, Fauzi, Manajemen Pendidikan Ala Rasulullah, 135.
} 
kuttab pada umat Islam Mekkah secara suka rela. Pasca hijrah ke Madinah, Rasulullah SAW memerintahkan kurang lebih 70 tawanan perang Badar kaum Quraisy Mekkah untuk mengajar sekitar sepuluh orang anak-anak muslim sebagai syarat pembebasan diri mereka. Walaupun pengajar di kuttab didominasi oleh orang dzimmi, Nabi Muhammad SAW juga memerintahkan beberapa sahabat seperti al Hakam ibn Sa'id untuk mengajar ketika Nabi berada di Madinah. ${ }^{13}$

Pada masa awal Islam ini, secara diametral terdapat dua bentuk kuttab, pertama, kuttab yang fokus pada pembelajaran baca tulis dengan menggunakan puisi kuno sebagai bahan ajar dan guru-gurunya sebagian besar adalah kaum kafir dzimmi. Kedua, selain baca tulis juga mengajarkan al-Qur'an dan dasardasar agama, hal ini terjadi setelah banyaknya muslim yang pandai baca tulis dan kehidupan masyarakat mulai stabil. ${ }^{14}$

Secara umum, selain baca tulis, materi pendidikan mencakup bidang pendidikan keagamaan, akhlak, dan kesehatan jasmani. Adapun materi-materi scientific belum dijadikan sebagai materi pelajaran. Nabi pada saat itu hanya memberikan stimulus untuk memperhatikan fenomena penciptaan manusia, hewan, tumbuh-tumbuhan, dan alam raya. ${ }^{15}$

Metode yang digunakan oleh Nabi dalam materi keimanan adalah tanya jawab dan ditunjang dengan bukti-bukti ilmiah dan rasional. Batasan ilmiah dan rasional di sini disesuaikan menurut kemampuan berpikir orang-orang yang diajak berdialog. Metode pendidikan yang dipakai pada bidang ibadah mayoritas menggunakan metode demonstrasi, yakni Nabi memberikan contoh tata cara beribadah sehingga masyarakat mudah mempraktikkannya. Sedangkan pada bidang akhlak, Nabi menitikberatkan pada metode

\footnotetext{
${ }_{13}$ Asari, Menyingkap Zaman Keemasan Islam, 24.

14 Baharuddin, Dikotomi Pendidikan Islam, 211.

15 Pada bidang keagamaan terdiri dari keimanan dan ibadah. Pendidikan akhlak lebih menekankan pada penguatan basis mental yang telah dilakukan pada periode Makkah. Pendidikan kesehatan jasmani lebih ditekankan pada penerapan nilai-nilai yang dipahami dari amaliah ibadah, seperti makna wudhu, shalat, puasa. Lihat, Suwendi, Sejarah dan Pemikiran Pendidikan Islam, 9-10.
} 
keteladanan dan ceramah dengan membacakan ayat-ayat al-Qur'an yang berisi kisah-kisah umat terdahulu. ${ }^{16}$

\section{Kuttab Periode Khulafa al-Rasyidin}

Sistem pendidikan Islam pada masa Khulafa al-Rasyidin dikelola secara mandiri, tanpa campur tangan pemerintah, kecuali pada masa khalifah Umar ibn Khattab yang menambahkan kurikulum yang seragam di lembaga kuttab. Pada kepemimpinan Abu Bakar, para sahabat yang memiliki pengetahuan keagamaan membuka majelis pendidikan masing-masing, sehingga di masa ini kuttab mencapai tingkat kemajuan yang berarti. Hal ini terjadi ketika Islam telah menaklukkan beberapa daerah dan menjalin hubungan bilateral dengan bangsa-bangsa yang memiliki peradaban unggul. ${ }^{17}$

Materi pendidikan kuttab yang diajarkan pada masa Khulafa al-Rasyidin melanjutkan materi-materi pada masa Rasulullah, yaitu belajar membaca dan menulis, membaca al-Qur'an dan menghafalnya, serta belajar pokok-pokok agama Islam, seperti cara wudhu, shalat, puasa, dan sebagainya. Selain itu, Umar memerintahkan rakyatnya agar anak-anak diajarkan berenang, memanah, dan mengendarai unta. Penambahan materi yang bersifat mengasah kemampuan psikomotorik tersebut dimaksudkan untuk mempersiapkan pemuda yang tangguh, mengingat pada masa itu situasi jazirah Arab rentan terjadi peperangan. Sedangkan pada masa Ali bin Abi Thalib yang hanya berkisar 5 tahun $(35-40 \mathrm{H})$, perhatian terhadap dunia pendidikan tidak sehebat khalifah terdahulu. Hal ini disebabkan ketidakstabilan situasi politik dalam negeri akibat peperangan antara Ali dengan Muawiyah. ${ }^{18}$

\footnotetext{
${ }^{16}$ Ibid, 11.

${ }^{17}$ Kemajuan lembaga kuttab ini terjadi ketika masyarakat muslim telah menaklukkan beberapa daerah dan menjalin kontak dengan bangsa-bangsa yang maju. Lembaga pendidikan ini menjadi sangat penting sehingga para ulama berpendapat bahwa mengajarkan al-Qur'an merupakan fardlu kifayah. Lihat, ibid, 12.

18 Walaupun berada dalam suasana peperangan yang berkepanjangan, namun pendidikan Islam khususnya pendidikan keagamaan tetap berlangsung. Hanya saja peperangan antara Ali dan Muawiyah berpengaruh pada perkembangan pendidikan. Masa-masa kejayaan pemerintahan khulafaur rasyidin terletak pada masa pemerintahan Umar bin Khattab serta
} 
Secara umum, pada masa Khulafa al-Rasyidin ilmu-ilmu duniawi dan filsafat belum dikenal sehingga tidak terdapat dalam materi pembelajaran. Situasi ini lebih disebabkan karena konstruk sosial masyarakat masih dalam pengembangan wawasan keislaman yang lebih dititikberatkan pada pengetahuan al-Qur'an dan hadits secara literal. Berbagai konflik politik, peperangan, dan upaya perebutan kekuasaan pada masa tersebut sedikit banyak mempengaruhi situasi pendidikan. Akan tetapi hal ini tidak mematahkan semangat kaum ulama dan cendekia untuk tetap menjalankan proses transfer keilmuan.

\section{Kuttab Periode Dinasti Ummayyah}

Secara esensial, praktik pendidikan Islam pada masa dinasti Ummayyah hampir sama dengan pendidikan pada masa Khulafa al-Rasyidin dari segi materi dan metodenya. Hanya saja perhatian para raja terhadap pendidikan dinilai kurang maksimal, sehingga bidang pendidikan dijalankan oleh peran ulama tanpa campur tangan pemerintah. Sistem pendidikan Islam ketika itu berjalan alamiah karena kebijakan-kebijakan pendidikan yang dikeluarkan pemerintah hampir tidak ditemukan. ${ }^{19}$

Pada zaman khalifah Abdul Malik bin Marwan gencar membangun kantor-kantor pemerintah Umawiyah sehingga kegiatan membaca dan menulis menjadi sangat penting peranannya dalam proses pembangunan negara. Maka sejak saat itu pertama kalinya para guru menjadikan rumah-rumahnya sebagai tempat mengajar menulis dan membaca. Secara individual mereka membangun kamar atau rumah-rumah sesuai standar yang semakin bertambah dalam mengajar membaca dan menulis. ${ }^{20}$

tujuh tahun pertama kepemimpinan Utsman bin Affan. Setelah itu timbul pergolakan politik yang berujung pembunuhan terhadap khalifah Utsman. Lihat, Haidar Putra Daulay, et.al., Pendidikan Islam dalam Lintasan Sejarah: Kajian dari Zaman Pertumbuhan sampai Kebangkitan (Jakarta: Kencana, 2013), 56-57.

${ }^{19}$ Suwendi, Sejarah dan Pemikiran, 14.

20 Ali al-Jumbulati dan Abdul Futuh al-Tuwaanisi, Perbandingan Pendidikan Islam (terj) H.M Arifin(Jakarta: PT. Rineka Cipta, 2002), 29. 
Pada masa Daulah Ummayyah, dinamika disiplin fiqh menunjukkan perkembangan yang berarti dengan lahirnya tokoh madzhab fiqh Imam Abu Hanifah di Irak dan Imam Malik ibn Anas di Madinah. Ilmu tafsir, nahwu, dan hadits berkembang pesat sehingga menambah dinamika pendidikan kuttab. Selain itu, terdapat sebuah kuttab di Balk yang bernama Kuttab Abul Qasim alBalkhi yang memiliki 3000 orang murid dan jumlahnya kian hari semakin bertambah, bahkan tiap desa telah berdiri sebuah kuttab. Pendidikan di kuttab merupakan pendidikan dasar sebelum memasuki pendidikan di masjid. ${ }^{21}$

Sejak abad kedua hijriyah perkembangan kuttab semakin pesat. Kurikulum antar daerah berbeda-beda sesuai dengan kebutuhan masingmasing. Pada masa itu prinsip-prinsip demokrasi dan kebebasan tercermin dalam sistem pendidikan dengan penggunaan metode yang variatif, salah satunya adalah metode yang menghubungkan antar bahan-bahan pelajaran yang satu dengan lainnya.

\section{Kuttab Periode Dinasti Abbasiyah}

Pada pemerintahan Harun al-Rasyid (786-809 M) dan putranya, alMa'mun (813-833 M) menjadi puncak perkembangan peradaban, kebudayaan, dan ilmu pengetahuan dalam Islam. ${ }^{22}$ Khalifah al-Ma'mun adalah pemimpin yang pertama kali membentuk badan wakaf. Ia berpendapat bahwa laju kegiatan keilmuan tidak hanya bergantung pada bantuan negara dan kedermawanan penguasa, tetapi juga membutuhkan upaya swadaya masyarakat untuk turut serta membiayai pelaksanaan pendidikan. ${ }^{23}$ Maka sejak pemerintahan al-Makmun, lembaga wakaf mulai ditangani oleh negara dengan

\footnotetext{
${ }^{21}$ Hal ini sebagaimana yang diuraikan oleh Imam Syafi'i: "di waktu aku masih kecil, aku adalah seorang yatim dalam asuhan ibuku. Ibuku memasukkan aku ke kuttab, di kala aku telah menamatkan al-Qur'an masuklah aku ke masjid. Lihat, Daulay et.al., Pendidikan Islam, 64.

${ }^{22}$ K. Ali, Sejarah Peradaban Islam (Jakarta: Srigunting, 1998), 52. Masa pemerintahan Harun alRasyid berada pada periode pertama (750-847). Pada masanya mencapai masa keemasan karena khalifah secara politis memegang dua kendali sekaligus, yaitu politik dan agama. Ia memanfaatkan kekayaan negara untuk kemanfaatan sosial, di antaranya membangun berbagai sarana pendidikan serta memberikan gaji yang tinggi untuk para ulama dan ilmuan. Lihat, Suwendi, Sejarah Sosial Pendidikan, 98-99.

${ }^{23}$ Asrahah, SejarahPendidikan Islam, 91.
} 
membentuk struktur kepengurusan yang bertanggungjawab langsung kepada masyarakat.

Materi pendidikan dasar pada masa daulah Abbasiyah memperlihatkan adanya unsur demokrasi, karena di samping materi pelajaran yang bersifat wajib (ijbari), juga ada materi yang bersifat pilihan (ikhtiari). Materi pelajaran yang bersifat wajib ialah al-Qur'an, shalat, doa, dan bahasa Arab, sedangkan materi pilihan antara lain: berhitung, nahwu, syair-syair, dan riwayat/tarikh Arab. ${ }^{24}$ Namun pelajaran ini tidak dapat dijumpai di seluruh penjuru karena masing-masing daerah terkadang berbeda penerapannya. ${ }^{25}$ Adapun metode pengajaran yang digunakan dikelompokkan menjadi tiga macam, yaitu lisan, hafalan, dan tulisan. ${ }^{26}$

Durasi belajar di kuttab dilakukan sejak pagi hingga waktu Ashar mulai hari Sabtu sampai hari Kamis dan libur pada hari Jum'at, tanggal 1 Syawal, Idul Adha serta hari tasyrik. Jam pelajaran terbagi menjadi tiga sesi, yaitu: pertama, pelajaran al-Qur'an dimulai dari pagi hingga waktu Dhuha. Kedua, pelajaran menulis dimulai pada waktu Dhuha hingga Dzuhur, setelah itu anak-anak diperbolehkan pulang untuk makan siang. Ketiga, pelajaran lain, seperti nahwu sharraf, syair, bahasa Arab, dan berhitung, dimulai setelah Dzuhur hingga Ashar. ${ }^{27}$ Hal yang perlu diperhatikan bahwa pada pendidikan kuttab tidak menggunakan sistem klasikal, tanpa bangku, meja, dan papan tulis. Guru mengajar muridnya dengan bergantian satu persatu, tidak ada buku standar yang dipakai.

\footnotetext{
24 Yunus, Sejarah Pendidikan Islam, 50.

${ }^{25}$ Di Maroko (Maghribi) hanya diajarkan al-Qur'an dan tulisannya. Di Andalusia diajarkan alQur'an, menulis syair, pokok-pokok nahwu sharraf dan khat. Di Tunisia (Afriqiyah) diajarkan al-Qur'an, hadits dan pokok-pokok ilmu agama, tetapi lebih mementingkan hafalan al-Qur'an. Lihat, Suwendi, Sejarah Sosial, 21.

${ }^{26}$ Asrahah, Sejarah Pendidikan Islam, 77-79.

27 Ibid, 50-51.
} 


\section{Analisis Historis dan Sosiologis Kuttab}

Hingga abad ke $4 \mathrm{H}$ kurikulum pendidikan yang dipakai kuttab masih sangat sederhana dan hanya menekankan pada baca tulis dan al-Qur'an. Akan tetapi sejak abad $8 \mathrm{H}$ kuttab telah memuat pengetahuan umum selain ilmu agama. Hal ini terjadi dikarenakan adanya persentuhan antara Islam dengan warisan budaya Hellenisme sehingga banyak membawa kontribusi pembaruan dalam kurikulum pendidikan Islam. Bahkan dalam fase berikutnya kuttab telah diklasifikasikan menjadi dua macam, yaitu kuttab yang mengajarkan pengetahuan non agama (secular learning) dan kuttab yang mengajarkan ilmu agama (religious learning). ${ }^{28}$

Dari beberapa uraian tentang kuttab dari masa ke masa, dapat dihasilkan beberapa catatan penting tentang analisis historis dan sosiologis dalam perjalanan sejarah kuttab, antara lain: ${ }^{29}$

Pertama, keberadaan lembaga pendidikan kuttab menunjukkan bahwa masyarakat memiliki tingkat kesadaran, komitmen, dan tanggungjawab yang tinggi untuk memajukan dan mengangkat harkat dan martabat manusia. Mereka memafhumi bahwa untuk mencapai tujuan tersebut dapat dilakukan dengan upaya optimalisasi pengembangan ilmu pengetahuan, kebudayaan, dan peradaban melalui kegiatan pendidikan.

Kedua, keberadaan berbagai lembaga pendidikan tersebut menunjukkan adanya kegiatan swadaya masyarakat melalui pendidikan yang berbasis masyarakat, yakni dari masyarakat, oleh masyarakat, dan untuk masyarakat.

Ketiga, lahirnya kuttab dan berbagai materi pendidikannya tidak berlangsung secara instan, melainkan secara bertahap disesuaikan dengan kebutuhan masyarakat dan perkembangan zaman. Hal ini tampak pada perkembangan materi pendidikan yang awalnya hanya baca tulis dan hafalan al-Qur'an, bertambah dengan berbagai ilmu sains dan filsafat. Semakin

\footnotetext{
28 Baharuddin, Dikotomi Pendidikan Islam (Bandung: PT. Remaja Rosdakarya, 2011), 212-213.

29 Abuddin Nata, Sejarah Sosial Intelektual Islam dan Institusi Pendidikannya (Jakarta: Raja Grafindo Persada, 2012), 213-214.
} 
bertambah luas syiar Islam, maka perkenalan dengan berbagai budaya asing semakin memperkaya khazanah keilmuan cendekia muslim.

Keempat, pertumbuhan dan perkembangan lembaga pendidikan didukung oleh berbagai pihak, yakni pemerintah, ulama, sufi, ahli bahasa, pedagang, tokoh agama, dan masyarakat. Kolaborasi tersebut menunjukkan adanya hubungan yang harmonis antar berbagai komponen dan kesadaran bahwa keberlangsungan lembaga pendidikan adalah tanggungjawab bersama, baik dalam hal pengelolaan ataupun pendanaannya.

Kelima, sejalan dengan perkembangan kuttab terdapat hubungan kausalitas dan saling mempengaruhi antara pendidikan dengan berbagai permasalahan yang terjadi di masyarakat. Setiap persoalan baru akan diupayakan cara penyelesaiannya, sehingga secara tidak langsung akan menambah cabang keilmuan dalam pendidikan.

\section{Perbandingan Kuttab dengan Pendidikan Dasar di Indonesia}

Pendidikan di kuttab adalah pendidikan dasar semisal TPA, TK/RA, SD/MI. Waktu kelulusan antara satu anak dengan lainnya tidak sama, tergantung tingkat kecerdasan dan ketekunan masing-masing anak. Apabila dibandingkan dengan sistem sekolah dasar di Indonesia, hal ini justru berbanding terbalik. Kelulusan ditentukan oleh keberhasilan dalam pelaksanaan Ujian Nasional (UN) yang sarat dengan kecurangan untuk mendongkrak nilai dengan tujuan memperbesar prosentase kelulusan di sekolah hingga 100\%. Setelah UN banyak yang menentang, akhirnya diubah dengan menyerahkan kelulusan siswa kepada masing-masing lembaga pendidikan. Kebijakan ini pun bukan tanpa masalah karena membuat peserta didik menjadi malas belajar, mereka beranggapan belajar atau tidak, akan tetap lulus. Dalam situasi ini, kecerdasan dan ketekunan menjadi hal yang 
terabaikan. ${ }^{30}$ Jika diamati, sistem pendidikan kuttab jauh lebih efektif dan efisien dibandingkan sistem pendidikan saat ini.

Sistem pendidikan Rasulullah SAW yang diaplikasikan dalam lembagalembaga pendidikan Islam klasik belum mengeluarkan pengakuan kelulusan berupa gelar atau ijazah. Aspek penilaian tertinggi murid terletak pada ketakwaan dan hafalan al-Qur'an. ${ }^{31}$ Sedangkan penentuan nilai dalam sistem pendidikan Indonesia dominan dalam ranah kognitif saja, terutama dalam UN. Dengan demikian, output sistem pendidikan dewasa ini adalah manusia yang lebih menonjolkan otak/logika daripada hati nurani dan lebih berorientasi pada kepentingan pragmatis.

Pendidikan masa klasik merupakan pendidikan yang memanusiakan manusia, yaitu mengoptimalkan segenap potensi manusia untuk menjalani kehidupan sebagai abdullah dan khalifatullah serta menjadi instrumen bagi pengembangan diri yang beorientasi pembebasan terhadap penindasan. Apabila dibandingkan dengan sistem pendidikan sekolah dasar di Indonesia, proses pendidikan ibarat kegiatan menabung (banking concept education) dengan memposisikan anak didik sebagai celengan dan pendidik sebagai penabungnya. guru memasukkan pengetahuan sesuai dengan acuan bahan pelajaran dalam kurikulum yang harus dituntaskan pada akhir tahun tanpa mempedulikan tingkat pemahaman siswa. ${ }^{32}$

\footnotetext{
${ }^{30}$ Dalam wacana ini, terdapat perbedaan persepsi antara masyarakat dan pemerintah tentang keberhasilan pendidikan. Masyarakat menempatkan makna pendidikan pada prioritas yang tinggi, namun dijawab oleh pemerintah dengan mengutamakan pencapaian target. Ini mengindikasikan bahwa yang diinginkan masyarakat adalah pelayanan yang bersifat kualitatif dan bermakna, yang kemudian direspon dengan usaha yang bersifat kuantitatif dengan angka. Sehingga birokrasi berkesimpulan bahwa kenaikan angka itu sudah sama dengan peningkatan kualitas. Lihat, Ade Irawan et.al., Buruk Wajah Pendidikan Dasar (Jakarta: Indonesia Corruption Watch, 2006), viii.

${ }^{31}$ Fauzi, Manajemen, 138.

32 Proses pendidikan harus memberikan kesempatan bagi peserta didik untuk berimprovisasi dalam menunjukkan eksitensi dirinya. Ketika sistem pendidikan berlangsung dengan gaya bank, maka akan menghasilkan generasi yang tidak mandiri dan bergantung. Sikap ketergantungan tersebut merupakan salah satu dampak negatif pendidikan model kapitalistik yang menghambat proses pemberdayaan diri dan masyarakat. Lihat, Umiarso dan Zamroni, Pendidikan Pembebasan dalam Perspektif Timur dan Barat (Jogjakarta: Ar-Ruzz Media, 2011), 17.
} 
Kuttab merupakan institusi pendidikan yang mayoritas merupakan institusi wakaf dari masyarakat. Masyarakat berswasembada dalam pembangunan dan pengembangannya, baik dalam hal pendanaan ataupun pengajaran yang disesuaikan dengan kebutuhan lokal. Sedangkan sekolah dasar negeri di Indonesia bergantung kepada pemerintah dalam operasionalnya sehingga tidak jarang terdapat sekolah roboh dan kekurangan tenaga pengajar karena menunggu bantuan pemerintah yang tak kunjung datang. Walaupun sebenarnya dana pendidikan berasal dari pajak yang notabene juga berasal dari rakyat, sesuai dengan amanat UUD 1945 bahwa pendidikan memperoleh porsi $20 \%$ dari APBN.

Secara umum, sistem pengelolaan pendidikan pada masa klasik lebih ditentukan oleh kekuatan ulama daripada penguasa negara. Baik pada masa Nabi hingga masa Abbasiyah, para tokoh agama memiliki otoritas untuk menentukan arah sistem pendidikan. ${ }^{33}$ Namun di Indonesia sistem pendidikan dipegang penuh oleh pemerintah dengan menunjuk orang yang dianggap mampu menduduki pos pendidikan. Sayangnya, ranah ini juga tidak luput dari politisasi pendidikan karena adanya sistem bagi-bagi kekuasaan, sehingga pemangku pendidikan nasional kadang kurang berkompeten di bidangnya. Setiap berganti menteri pendidikan berganti pula kurikulum yang dipakai, akibatnya baik guru ataupun peserta didik sama-sama kebingungan dan proses pembelajaran menjadi terhambat.

\section{Full Day School Sebagai Regenerasi Kuttab di Era Kekinian}

Modernisasi menuntut diferensiasi sistem pendidikan untuk mengantisipasi dan mengakomodasi berbagai diferensiasi sosial, teknik, dan manajerial. Antisipasi dan akomodasi tersebut haruslah dijabarkan dalam bentuk formulasi, adopsi dan implementasi kebijaksanaan pendidikan dalam tingkat nasional, regional dan lokal. ${ }^{34}$ Dalam konteks modernisasi administatif

\footnotetext{
33 Suwendi, Sejarah dan Pemikiran, 28.

34 Azyumardi Azra, Pendidikan Islam. (Jakarta: Kencana, 2012), 33.
} 
ini, sistem dan lembaga pendidikan Islam perlu bersimbiosis ke dalam sistem sekolah.

Di tengah carut marutnya pendidikan Indonesia, berbagai upaya yang telah dilakukan oleh umat Islam. Pendidikan sebagaimana yang diterapkan dalam sejarah klasik sesungguhnya masih relevan untuk dipertimbangkan dan dijadikan sumber inspirasi. Karena pada dasarnya, kebutuhan terhadap sekolah tidak hanya cukup memberikan asupan kognitif, melainkan sekolah yang dapat memberikan pemahaman nilai dan kearifan hidup. Terlebih di daerah perkotaan, di mana orang tua sibuk bekerja sehingga rasa aman dan kewajiban memberikan ilmu agama terhadap anak kurang terpenuhi. Maka berdasar pada hal tersebut, lembaga pendidikan dasar Islam swasta menjadi penggerak utama penerapan konsep Full Day School yang kegiatan belajar mengajarnya menyerupai sistem pembelajaran kuttab.

Telah dimafhumi sebelumnya, bahwa sistem pendidikan kuttab klasik berlangsung dari pagi hingga sore hari setelah Ashar. Materi yang diberikan pun semakin berkembang yaitu kolaborasi antara ilmu agama dan ilmu umum yang terbagi dalam materi wajib dan materi pilihan.Walaupun waktu belajar relatif lama, namun anak didik tidak kehilangan waktu untuk beristirahat, karena ketika Dzuhur mereka diberi kesempatan pulang untuk makan siang dan melepas penat sebelum akhirnya kembali lagi ke kuttab untuk melanjutkan pelajaran. Kegiatan pembelajaran ini pada awalnya diterapkan dengan pola presciptive, yaitu pembentukan sebuah budaya yang berbeda terhadap peserta didik baru melalui skenario, tradisi, atau perintah dari atas (pendidik). Lamakelamaan menjadi learning process yaitu sebuah keyakinan yang dipegang teguh oleh peserta didik sebagai pendirian dan diaktualisasikan melalui sikap dan perilaku belajar dengan penuh kesadaran. ${ }^{35}$

Sementara Full Day School merupakan sistem pendidikan yang menjalankan kegiatan belajar mengajar sehari penuh dengan menambah jam pelajaran sebagai pendalaman materi serta pengembangan diri dan kreatifitas.

35 Taliziduhu Ndraha, Teori Budaya Organisasi (Jakarta: Rineka Cipta, 1999), 24. 
Full Day School menciptakan model sekolah yang memadukan sistem pengajaran Islam secara intensif dengan menambah waktu khusus untuk penguatan keagamaan siswa. Umumnya jam tambahan tersebut diletakkan setelah sholat Dhuhur sampai sholat Ashar, sehingga sekolah model ini masuk pukul 07.00 WIB pulang pada pukul 16.00 WIB, sama sebagaimana waktu belajar di kuttab. Pendalaman agama diisi dengan tadarrus dan kajian alQur'an, bimbingan shalat, bahasa Arab, serta wawasan keislaman lainnya. Yang sedikit membedakan antara kuttab dan sekolah Full Day School adalah pada waktu istirahat, jika kuttab mengizinkan siswa untuk makan siang di rumah, maka di Full Day School makan siang tetap dilaksanakan di sekolah dengan adanya tambahan biaya untuk catering makan. Kegiatan semacam ini telah menjadi rutinitas keseharian, sebagaimana pendapat aliran behavioristik bahwa sesuatu yang dikerjakan berulang-ulang dalam waktu yang sama akan menjadi sebuah kebiasaan. ${ }^{36}$

Sejarah pemberlakuan Full Day School di lembaga pendidikan Islam di Indonesia berbeda dengan Full Day School di Amerika Serikat sebagai negara pencetusnya di era 80-an. Jika di Amerika Full Day School dilatarbelakangi oleh semakin banyaknya kaum ibu yang bekerja di luar rumah dan kekhawatiran terhadap pengaruh negatif televisi, maka di Indonesia Full Day School hadir karena keinginan orang tua untuk memasukkan anaknya ke sekolah unggulan. Walaupun pada perkembangan selanjutnya, Full Day School dijadikan rujukan karena kaum ibu Indonesia juga banyak yang menjadi wanita karier sehingga memerlukan sekolah yang mampu merepresentasikan peran orang tua dalam memberikan asupan nilai agama dan pendidikan kognitif. ${ }^{37}$

\footnotetext{
36 Emna Laisa, Optimalisasi Pendidikan Agama Islam di Sekolah melalui Pengembangan Budaya Religius (Studi Pada SMK Darul Ulum Bungbungan Bluto Sumenep), (Islamuna: Jurnal Studi Islam 3 (1), 90.

${ }^{37}$ Munculnya sistem pendidikan Full Day School di Indonesia diawali dengan populernya istilah sekolah unggulan sekitar tahun 1990-an, yang banyak dipelopori oleh sekolah-sekolah swasta termasuk sekolah-sekolah yang berlabel Islam. Dalam pengertian yang ideal, sekolah unggul adalah sekolah yang fokus pada kualitas proses pembelajaran yang berkaitan erat dengan sistem pembelajaran yang bagus. Namun sejauh ini, sekolah unggulan biasanya ditandai dengan biaya yang mahal, fasilitas yang lengkap dan serba mewah, elit, lain daripada yang
} 
Ditilik dari kurikulumnya, sistem pendidikan Full Day School memiliki relevansi dengan pendidikan terpadu yang diterapkan dalam kuttab dengan model integrasi dan interkoneksi ilmu pengetahuan. Pendidikan terpadu ini banyak diterapkan dalam lembaga pendidikan swasta berlabel Islam. Dalam konteks pendidikan Islam, pendidikan terpadu artinya memadukan ilmu umum dengan ilmu agama secara seimbang dan terpadu. Model pendidikan terpadu ini menjadi alternatif penghapusan dikotomi ilmu umum dan ilmu agama dalam pendidikan. Kuttab dan full day scholl sama-sama menerapkan kurikulum yang mengakomodasi dan mengadaptasi karakteristik lokal. Sehingga ranah aplikasinya sejalan dengan kebutuhan lingkungan.

Dalam kuttab ataupun Full Day School semua program dan kegiatan siswa, baik belajar, bermain, beribadah dikemas dalam sebuah sistem pendidikan. Titik tekan pada kedua lembaga pendidikan tersebut adalah siswa yang takwa dan berprestasi serta membawa perubahan positif dari setiap individu siswa sebagai hasil dari proses dan aktivitas dalam belajar. Selain itu, Full Day School membantu orang tua untuk memberikan pelajaran agama yang kurang terpenuhi karena orang tua yang sibuk atau minim pengetahuan agama tanpa membuat anak menjadi tertekan. Hal ini disebabkan karena pertama, proses pembelajaran yang dirancang secara aktif, kreatif, tranformatif sekaligus intensif. Kedua, proses pembelajaran sehari penuh tidak memforsir siswa pada pengkajian dan penelaahan yang terlalu menjenuhkan, tetapi yang difokuskan adalah sistem relaksasi yang santai dan lepas dari jadwal yang membosankan. ${ }^{38}$

Secara keseluruhan, Kuttab dan Full Day School merupakan dua macam institusi pendidikan beda generasi yang memiliki kesamaan dalam ranah aplikasinya. Jika Full Day School adalah produk unggul hasil tempaan zaman,

lain, serta tenaga-tenaga pengajar yang profesional, walaupun keadaan ini sebenarnya tidak menjamin kualitas pendidikan yang dihasilkan. Istilah unggulan ini yang kemudian diformat dan dijual oleh para pengelola sekolah menjadi bentuk yang lebih beragam dan menjadi trade mark, diantaranya adalah fullday school dan sekolah terpadu. Lihat, Iwan Kuswandi, Full Day School dan Pendidikan Terpadu, http://iwankuswandi.wordpress.com, diakses pada 27 September 2019.

38 Nor Hasan, Full day School (Model alternatif pembelajaran bahasa Asing). (Tadris: Jurnal Pendidikan. Vol 1(1), 2006), 110-111. 
RABBANI

maka kuttab adalah prototype awalnya. Dari adanya evolusi ini dapat ditarik kesimpulan bahwa sistem pendidikan kuttab memiliki kontribusi besar dalam upaya memajukan sistem pendidikan Islam dari masa ke masa.

\section{KESIMPULAN}

Dalam perjalanan sejarah kuttab dari masa Rasulullah hingga daulah Abbasiyah, secara umum, masyarakat dan pemerintah memiliki peran signifikan dalam keberlangsungan pendidikan, baik segi pembiayaan dan pelaksanaannya. Ketika membandingkan sistem kuttab dengan pendidikan dasar di Indonesia, di luar kemajuan teknologi, akan tampak berbagai kekurangan dalam sistem pendidikan dewasa ini. Dengan wacana almuhafadzah ala al-qadim al-shalih wa al-akhdu bi al-jadid al-ashlah, masyarakat dan pemerintah hendaknya lebih konsen dalam usaha memajukan pendidikan. Salah satunya dengan melihat keberhasilan kuttab masa klasik untuk ditelaah kembali dan dijadikan inspirasi untuk dijadikan prototype model pendidikan di era kekinian.

\section{DAFTAR PUSTAKA}

al-Jumbulati, Ali dan Abdul Futuh al-Tuwaanisi. Perbandingan Pendidikan Islam (terj) H.M Arifin. Jakarta: PT. Rineka Cipta, 2002.

Ali, K. Sejarah Peradaban Islam. Jakarta: Srigunting, 1988.

Asari, Hasan. Menyingkap Zaman Keemasan Islam. Bandung: Mizan, 1984.

Asrahah, Hanun. Sejarah Pendidikan Islam. Jakarta: PT. Logos Wacana Ilmu, 1999.

Azra, Azyumardi. Pendidikan Islam. Jakarta: Kencana, 2012.

Baharuddin. Dikotomi Pendidikan Islam. Bandung: PT. Remaja Rosdakarya, 2011

Daulay, Haidar Putra et.al. Pendidikan Islam dalam Lintasan Sejarah: Kajian dari Zaman Pertumbuhan sampai Kebangkitan. Jakarta: Kencana, 2013.

Fajar, Abdullah. Peradaban dan Pendidikan Islam. Jakarta: Rajawali Press, 1996. 
Fauzi, Imron. Manajemen Pendidikan Ala Rasulullah. Jogjakarta: Ar-Ruzz Media.

Hasan, Nor. Fullday School (Model alternatif pembelajaran bahasa Asing). Tadris: Jurnal Pendidikan. Vol. No. 1 (Mei 2006)

Irawan, Ade et.al. Buruk Wajah Pendidikan Dasar (Jakarta: Indonesia Corruption Watch, 2006.

Laisa, Emna. Optimalisasi Pendidikan Agama Islam di Sekolah melalui Pengembangan Budaya Religius (Studi Pada SMK Darul Ulum Bungbungan Bluto Sumenep). Islamuna: Jurnal Studi Islam Vol. 3 No. 1 (Januari 2016)

Makdisi, George. The Rise of Colleges. Edinburg: Edinburg University Press, 1981.

Nakosteen, Mehdi. History of Islamic Origins of Western Education A.D 800-1350. Colorado: University of Colorado Press, 1964.

Nata, Abuddin. Sejarah Sosial Intelektual Islam dan Institusi Pendidikannya. Jakarta: Rajawali Pers, 2012.

----------- Sejarah Pendidikan Islam Pada Periode Klasik dan Pertengahan. Jakarta: Rajawali Pers, 2012.

Ndraha, Taliziduhu. Teori Budaya Organisasi. Jakarta: Rineka Cipta, 1999.

Sanjana, Wina. Kurikulum dan Pembelajaran (Teori dan Praktik Pengembangan Kurikulum Tingkat Satuan Pendidikan). Jakarta: Kencana, 2010.

Suwendi. Sejarah dan Pemikiran Pendidikan Islam. Bandung: Raja Grafindo Persada, 2004.

Suwito. Sejarah Sosial Pendidikan Islam. Jakarta: Kencana, 2005.

Syalabi, Ahmad. Sejarah Pendidikan Islam (terj. Muhtar Yahya). Jakarta: Bulan Bintang, 1973.

Uhbiyati, Nur. Ilmu Pendidikan Islam. Bandung: CV. Pustaka Setia, 2005.

Umiarso dan Zamroni. Pendidikan Pembebasan dalam Perspektif Timur dan Barat. Jogjakarta: Ar-Ruzz Media, 2011.

Yunus, Mahmud. Sejarah Pendidikan Islam. Jakarta: Hidakarya Agung, 1992.

Zuhairini et.al,. Sejarah Pendidikan Islam. Jakarta: PT. Bumi Aksara, 2011. 